\title{
Impacts of Climate Change on Socio-Economic Sector and Health profile in the interior Coast, Bangladesh: the Case Study of Dumuria Upazilla, Khulna, Bangladesh
}

\author{
Rezaul Karim¹, Mohammed Mohinuzzaman², Shahrin Rahman², \\ Anuradha Rani ${ }^{4}$ \\ ${ }^{1,4}$ (Department of Environmental Science and Technology, Jessore Science and Technology University, \\ Bangladesh) \\ ${ }^{2}$ (Department of Environmental Science and Hazards Studies, Noakhali Science and Technology University, \\ Bangladesh \\ ${ }^{3}$ (Department of Environmental Sciences, Jahangirnagar University, Bangladesh)
}

\begin{abstract}
The main objective of the study was to define socio-economic and health status with the context of climate change in the interior coastal region of the Bay of Bengal. There were selected three villages of Dumuria upazila, Khulana, Bangladesh in order to address the objectives. Both secondary data and primary data through participatory approaches e.g. Personal Interviews (15 participants per village) were considered. From the field survey, the stratification of wealth group indicated that the poor groups embodying the largest number of household and the major economic activity among the respondents is agriculture, the most vulnerable sector of climate change are high level of vulnerability of communities in the study area. The local people (64.44\% of the respondents) perceived the increase in temperature and precipitation over the 7 years. From the empirical climatic data, there were also observed the fluctuations of humidity and rainfall; temperature trend was also observed that the winter is becoming cooler but the summer is hotter. Therefore, there were also found that the fluctuations of the crops production with seasonal variations. On the context of health concern, nutritional status was found well with adequate food and safe drinking water and also using hygiene sanitation. There were also reported some health problems those are related to climatic phenomenon.

Keywords: Climate change, People Perception, Crop Production, Health Status
\end{abstract}

\section{INTRODUCTION}

Climate change is hastily emerging as one of one of the most severe global problems affecting the 'global physical threats to the environment and public health' [1] . Various human activities are making the world hot to hotter and enhancing the trends of changing climatic phenomenon [2]. It is also considered to be one of the most serious threats to sustainable development with adverse impact on environment, human health, food security, economic activities, natural resources and physical infrastructure [3, 4]

According to the IPCC assessments and other available reports, tropical and subtropical countries would be more vulnerable to the potential impacts of global warming. It was concluded south Asia is particularly vulnerable to the impacts of climate change because of factors such as widespread poverty, recurrent droughts, and inequitable land distribution and over dependence on rain-fed agriculture [3]

Bangladesh is likely to be one of the worst hit countries, being an Asian and a third world country [5]. The maximum temperature range is 36.6 to 40.55 degree centigrade in summer and minimum temperature range is 7.22 to 2.77 degree centigrade in winter. The average rainfall varies from 119.38 to $348.16 \mathrm{~cm}$ [6]. These changing trends of climate are affecting almost every sector of socio-economic life in Bangladesh [7]. The main threats are likely to increased flooding, drainage congestion, decrease of fresh water availability, disturbance of morphological processes, salinity intrusion, frequent cyclone and storm surge flooding. Most vulnerable socioeconomic resource and sectors are coastal resources, water resources, agriculture, human health and ecosystem or biodiversity [8].

The impact of global climate change on agriculture has been studied extensively for various crops at different in many countries of the world [3]. The economy of Bangladesh is based on agriculture, industry and service. The agriculture sector contributes a major share in the GDP, which is about $30 \%$ and employs about $63 \%$. The variability of climate change has become a challenge issue for agriculture due to global warming.

Agricultural crops of Bangladesh are especially sensitive to the different variables of climate such as temperature, rainfall, humidity, and day - length etc. as well as different natural disasters like floods, drought, salinity and storm surges etc [5]

Climate change poses substantial risks to human health in Asia. The nutritional status will also be threatened due to climate-change-attributes. Global burden (mortality and morbidity) of diarrhoeal and 
malnutrition are already the largest in South and Southeast Asian countries including Bangladesh, Bhutan, India, Maldives, Myanmar and Nepal in 2000 [8]. The relative risks for these conditions for 2030 are expected to be also the largest. [9]. There are also evidenced other health problems e.g. dysentery, tuberculosis, pneumonia, dermatitis, malnutrition, anaemia, eye disease and high blood pressure

The main objective of the study was to define socio-economic and health profile with the context of climate change in the interior coastal region, Bangladesh. The specific objectives were to know the local perception on climate change in the study area; to define the climatic trends from the empirical data in the study area; to find out the change of crop production with climate change and to lay out the health profile of the region.

\subsection{Description of the study area}

\section{RESEARCH METHODOLOGY}

The study was carried out in three villages namely, Angardoha, Goturia and Borodanga of Dumuria upazila, Khulna, Bangladesh. It is located at $22^{\circ} 48^{\prime} 30^{\prime \prime} \mathrm{N} 89^{\circ} 25^{\prime} 30^{\prime \prime} \mathrm{E}$ or $22.8083^{\circ} \mathrm{N} 89.4250^{\circ} \mathrm{E} / 22.8083$; 89.4250 (figure 2-1). The region occupies extensive low-lying area between the Ganges River Floodplain and the Ganges Tidal Floodplain (14th Agro Ecological Zone, namely Gopalgong Khulna Bil) [10]. General mainly peat and non-calcareous dark grey floodplain soils are present in this region. Fertility level is medium due to medium to high organic matter content and low $\mathrm{P}$ and $\mathrm{Zn}$ substance being potentially strongly acid [11]. The region is also influenced by the discharge huge amount of water and sediments to the Bay of Bengal in the south. These are involved to dynamic actions leading to coastal erosions and accretions and other phenomena [10].

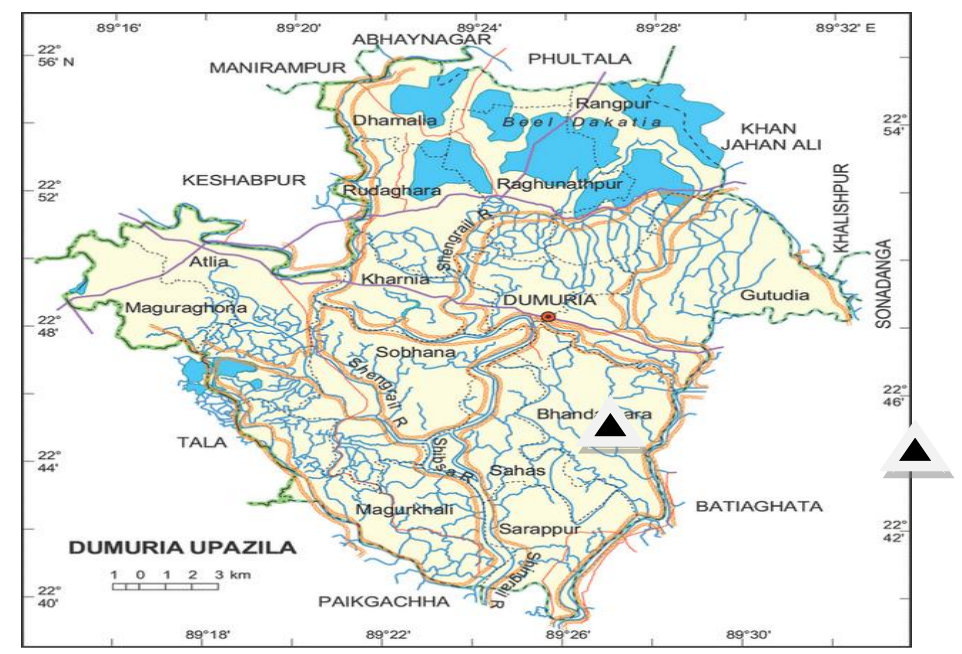

Figure II-1 Map of the study area [10]

The coastal zone of Bangladesh is characterized by a fast growing population and workforce. A total of 36.8 million people live in the coastal zone of Bangladesh (2001 census) [12]. Dumuria is also highly populated (256503, Males $51.12 \%$ and females $48.88 \%$ ). Extent of poverty in coastal zone is relatively high compared to remaining part of the country 52\% are absolute poor and $25 \%$ are extreme poor [12] but there were also some potential shrimp culture and also an exportable commodity in the world market e.g. fish drying. There are also some other related opportunities, including shell collection, crab tattering, natural and artificial pearl culture, turtle culture, crocodile farming, production of fish feed and sea weeds [13].

\subsection{Climatic conditions in the study area}

The maximum and minimum temperatures usually range from $40^{\circ} \mathrm{C}$ to $29^{\circ} \mathrm{C}$ and $5^{\circ} \mathrm{C}$ to $25^{\circ} \mathrm{C}$ respectively. The average annual rainfall during $1965-1990$ was about $1,750 \mathrm{~mm}$. The average relative humidity in the dry season ranges from 64 to 75 percent and in the wet season from 75 to 87 percent [10]

\subsection{Data Collection and Analysis}

Both secondary and primary data were collected in order to address the objectives of this study. The climatic data and agricultural production records were collected from the upazila agricultural extension office, Dumuria, Khulna. Other related to climate and agriculture was collected from the documents published by the Departments of Environment, Disaster and Policy of Ministry of BD, and from Bangladesh Meteorological Board. Others sources also included books, government reports, international reports, scientific journals, maps and news articles. 
Mainly participatory approach e.g. Personal Interview was followed for the field research work of the thesis. There were at total number of 15 participants per village. The discussion period was not too long and too short but in an appropriate level. In interview period, it was in keen attention in the process of listening, paraphrasing, probing, and note taking. After completing interview, there were three set of reports from each village. These were segregated and compiled. It was semi-structured questionnaire survey.

Tables and bar charts were used to present different variables. Cross-tabulation allowed a comparison of different study parameters in the three villages. Temperature and rainfall data from meteorological stations were analyzed using Microsoft Office Excel 2007 to present patterns and trends of rainfall and temperature in the form of graphs.

There were followed several sectors e.g. Nutritional status, Water and sanitation system and occurrence of climate related disease and treatment facilities in consideration to define the health profile of the study area. The Nutritional status was analyzed through Food Consumption Score (FCS) followed the "Food Consumption Score (FCS) in Bangladesh Context Technical Guideline January 2009".

Table II-1 Food Consumption Score (FCS) in Bangladesh Context

\begin{tabular}{|c|c|c|c|c|}
\hline Food items (examples) & $\begin{array}{l}\text { Food group } \\
\text { (definitive) }\end{array}$ & $\begin{array}{l}\text { Weight } \\
\text { (definitive) }\end{array}$ & $\begin{array}{l}\text { How many days } \\
\text { was the food item } \\
\text { eaten in previous } 7 \\
\text { days? }\end{array}$ & $\begin{array}{l}\mathrm{FCS}= \\
\text { frequency } * \text { weight }\end{array}$ \\
\hline $\begin{array}{l}\text { Maize, rice, bread and other } \\
\text { cereals }\end{array}$ & Main staples & 2 & & \multirow{2}{*}{$\begin{array}{l}\text { FCS Profiles } \\
0-21 \text { Poor } \\
21.5-35 \text { Borderline } \\
>35 \text { Acceptable }\end{array}$} \\
\hline $\begin{array}{l}\text { Beans, groundnuts, Peas, } \\
\text { and cashew nuts }\end{array}$ & Pulses & 3 & & \\
\hline $\begin{array}{l}\text { Vegetables, relish and } \\
\text { leaves }\end{array}$ & Vegetables & 1 & & \multirow{6}{*}{$\begin{array}{l}\text { A score of } 21 \text { was set as the } \\
\text { minimum food } \\
\text { consumption composed by } \\
\text { an expected daily } \\
\text { consumption of staple } \\
\text { (frequency*weight, } 7 * 2= \\
\text { 14) and vegetables }(7 * 1= \\
7) \text {. }\end{array}$} \\
\hline & Fruit & 1 & & \\
\hline $\begin{array}{l}\text { Beef, goat, poultry, eggs } \\
\text { and fish }\end{array}$ & Meat and fish & 4 & & \\
\hline Milk and other diary & $\begin{array}{l}\text { Milk and } \\
\text { milk products }\end{array}$ & 4 & & \\
\hline Sugar and sugar products & sugar & .5 & & \\
\hline Oils, fats and butter & oil & .5 & & \\
\hline
\end{tabular}

\subsection{Crop pattern in the study area}

Although there are grown different varieties of crops in Bangladesh, rice is the overwhelmingly dominant crop in terms of acreage and importance as the staple food. Rice alone accounts for about 75 per cent of the cropping area in the country. In terms of acreage, other important crops grown in the country are wheat (4.4 per cent), jute ( 3.9 per cent), potato (1.1 per cent), pulses ( 2.79 per cent), sugarcane (1.12 per cent), and chilli (1.05 per cent), and oil seeds (3.08 per cent). In addition, onion, gram, garlic and groundnut, etc. are cultivated on a relatively small scale [14]

The annual crop-growing period in Dumuria is divided into three main seasons, named locally as kharif I, kharif II and rabi. The seasonal characteristics and cropping pattern in the study area are shown in the Table 21.

Table II-2 Seasonal characteristics of the study area $(*[14])$

\begin{tabular}{|l|l|l|l|}
\hline \multicolumn{1}{|c|}{ Characteristics } & Kharif I & Kharif II & Rabi \\
\hline Duration & March to June & July-October & October-March \\
\hline $\begin{array}{l}\text { Climatic } \\
\text { conditions }\end{array}$ & $\begin{array}{l}\text { high temperatures, } \\
\text { low rainfall and } \\
\text { high humidity }\end{array}$ & $\begin{array}{l}\text { high temperatures, } \\
\text { rainfall and } \\
\text { high humidity }\end{array}$ & $\begin{array}{l}\text { dry, sunny weather that } \\
\text { gradually becomes colder } \\
\text { in the months of December } \\
\text { through to February }\end{array}$ \\
\hline Cropping patterns & $\begin{array}{l}\text { Aus rice and Jute, oil seed } \\
\text { crops and vegetables }\end{array}$ & $\begin{array}{l}\text { Transplanted Aman rice and } \\
\text { vegetables }\end{array}$ & $\begin{array}{l}\text { Boro rice, oil seed crops, } \\
\text { pulses crops, spices crops, } \\
\text { vegetables crops, potato }\end{array}$ \\
\hline $\begin{array}{l}\text { Depending } \\
\text { parameters }\end{array}$ & $\begin{array}{l}\text { Small amount of rain and } \\
\text { mostly depend on } \\
\text { irrigation }\end{array}$ & $\begin{array}{l}\text { During this period, the } \\
\text { moisture supply from } \\
\text { rainfall plus soil storage is } \\
\text { enough to support rainfed } \\
\text { crops. }\end{array}$ & $\begin{array}{l}\text { The crops grown in the } \\
\text { rabi season are largely } \\
\text { dependent on surface as } \\
\text { well as groundwater } \\
\text { irrigation }\end{array}$ \\
\hline
\end{tabular}

*Field survey 2013 and upazila agriculture office, Dumuria, Khulna.

\section{RESULT AND DISCUSSION}

\subsection{Socio-economic profile of the study area}

The people of the three villages are freely living in their society. The social relation among the people is very good. They are involved in many professional works. So their occupations are also different as well as their economic condition. 


\section{Wealth stratification}

In the study villages, three major social groups were identified. These are: the rich group; the medium rich group and the poor group. Their proportions of the groups were provided by the local people as presented in Table 3-1. Generally the stratification of the surveyed villages indicated that the poor group embodying the largest number of households. The percentage of rich category is low in among villages which implies that a high level of vulnerability of communities in these villages (Table 3-1). Based on the characteristics of the three wealthy groups, it implies that vulnerabilities and adaptive capacities among groups vary accordingly in the three villages studied.

Table III-1: Distribution of wealth group in the study area

\begin{tabular}{|l|l|l|l|l|}
\hline $\begin{array}{l}\text { Name of the } \\
\text { villages }\end{array}$ & $\begin{array}{l}\text { Total number } \\
\text { of households }\end{array}$ & $\begin{array}{l}\text { Rich } \\
\text { Group, \% }\end{array}$ & $\begin{array}{l}\text { Medium } \\
\text { rich group, \% }\end{array}$ & $\begin{array}{l}\text { Poor } \\
\text { Group, \% }\end{array}$ \\
\hline Total & $45(100)$ & $6(14)$ & $25(55)$ & $15(33)$ \\
\hline
\end{tabular}

\subsection{Major economic activities of the study area}

Agriculture is the major economic activity for $(51.11 \%)$ of the respondents in three villages (Table 32). 'Day labor' is the second major economic activity in these villages (about $31.11 \%$ ). Fishing and business ranked as the third economic activity (about 6.66\%). But the less number of these respondents do government service or private jobs which are only $4.44 \%$. Other minor economic activities included poultry, livestock raring which were common in Angardoha village and was mainly done by women. According to interviews this activity has increased recently. In addition, currently there has been an increase in the number of women involved in collection and selling of firewood. This is unlike in the past when these activities were only undertaken by men.

Table III-2: Occupational status of the respondents

\begin{tabular}{|l|l|}
\hline Occupation & Percentage (\%) \\
\hline Agriculture & 51.11 \\
\hline Business & 6.66 \\
\hline Fishing & 6.66 \\
\hline Job & 4.44 \\
\hline Day labour & 31.11 \\
\hline
\end{tabular}

\subsection{Local perceptions on climate changes}

According to the field survey, it was reported that changing rainfall is the main climatic problems that causes to hamper crop production ( $49 \%$ of respondents); temperature and cyclone is the second responsible to damage the agricultural production and causing health problems as $23 \%$ of people each were responded. There are also some effects by sea level rise casing sea water intrusion.

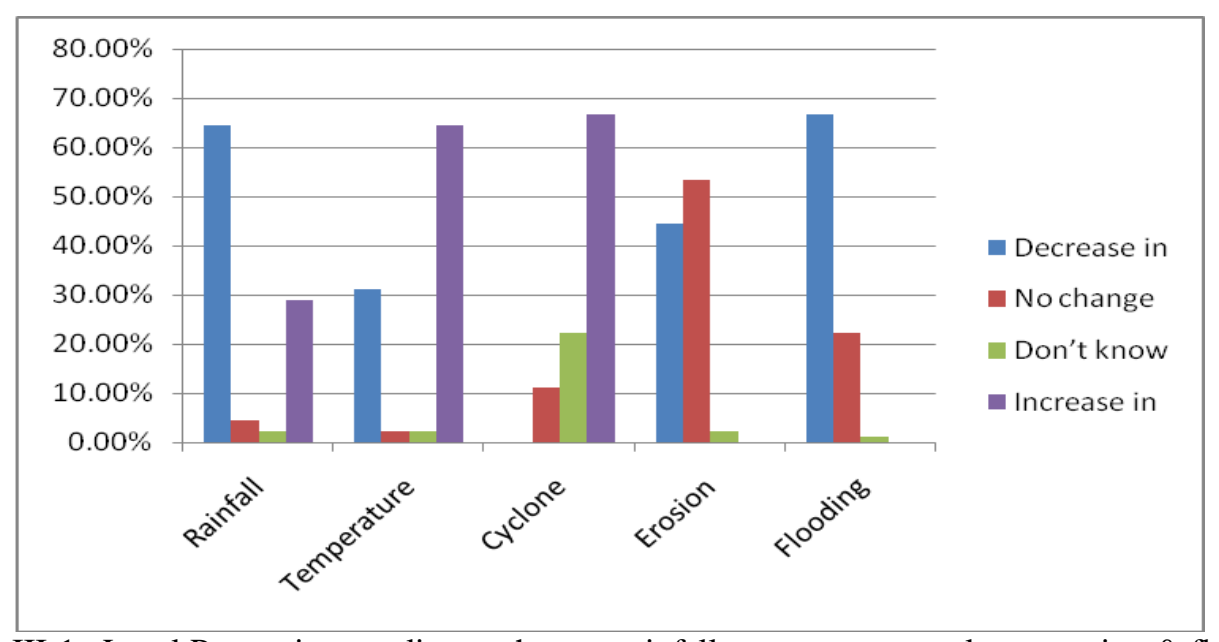

Figure III-1: Local Perception on climate change: rainfall, temperature, cyclone, erosion \& flooding

Fig 3-1 shows that (64.44\%) of the respondents in Dumuria Upazila perceived the increasing trends in temperature and decreasing precipitation over the 7 years. Otherwise majority respondents in Dumuria Upazila that Cyclone, Erosion, Flooding ( $0 \%$ ) increase but majority respondents that $(28.89 \%)$ and $(31.11 \%)$ decrease in precipitation and temperature they also declared that Cyclone, Erosion and Flooding (66.67\%), (44.44\%) and (66.67\%) decrease. 


\subsection{Comparative trends of Climate Change between Bangladesh and in the study area}

\subsubsection{Present Scenario and Projection of climate change in Bangladesh}

The vulnerability to climate change varies across the countries over the whole world. This can be characterized by geomorphologic and geographical region with predominant ecosystem systems. The existing vulnerability of Bangladesh is related to flood (riverine and flash flood), drought, salinity, cyclone and storm surges, and river bank and soil erosion. In Bangladesh NAPA (2005) it is stated that the duration of rainy season has been decreased but the total annual rainfall remains more or less same. It means that heavy rainfall is occurred within short period [15]. It was reported that the average increase in temperature would be $1.3^{\circ} \mathrm{C}$ and $2.6^{\circ} \mathrm{C}$ for the two projection years, 2030 and 2075 , respectively while in 2075 there would not be any appreciable rainfall in winter [16]. The observed climatic data from 1971 to 2002 indicate that the temperature is increasing in the monsoon season (June, July and August). Average winter season (December, January and February) maximum and minimum temperature show respectively a decreasing and an increasing trend annually at $0.001{ }^{\circ} \mathrm{C}$ and $0.016^{\circ} \mathrm{C}$ [6]. The average monsoon maximum and minimum temperatures show an increasing trend annually at $0.05^{\circ} \mathrm{C}$ and $0.03^{\circ} \mathrm{C}$, respectively [17]. On the other hand, monsoon precipitation would increase at a rate of $12 \%$ and $27 \%$ for the two projection years, respectively[16]. Quadir and Iqbal (2008) studied rainfall data from 1951 to 2007 of 9 coastal BMD stations and found that only 5 stations showed increasing trend, while 4 stations showed negative trend for monsoon period rainfall [17].

There was a study undertaken by World Bank (2000) to predict the sea level rise and their expected consequences in the coastal region, Bangladesh. This showed $10 \mathrm{~cm}, 25 \mathrm{~cm}$ and $1 \mathrm{~m}$ rise in sea level by 2020 , 2050 and 2100. It is also reported $1.0 \mathrm{~cm}$ per year sea level rise in Bangladesh [18]. If it happens then the SLR only will affect $2 \%, 4 \%$ and $17.5 \%$ of total land mass respectively [18]. A study by SAARC Meteorology Research Centre found that tidal level in Hiron Point, Char Changa and Cox's Bazaar raised $4.0 \mathrm{~mm} / \mathrm{year}, 6.0$ $\mathrm{mm} /$ year and $7.8 \mathrm{~mm} /$ year respectively [19].

Quadir and Iqbal (2008) have reported the tropical cyclones of the Bay of Bengal for the period of 131 years (1877-2007). There has been a significant increasing trend in the cyclone frequency over the Bay of Bengal at the main months for cyclone (November and May) [19]. For cyclone intensity, an increase in SST will be accompanied by a corresponding increase in cyclone intensity [20]. It was found that while the frequency of Depression (D: wind speed 40-50 km/hr), Cyclonic Storm (CS: wind speed 62-88 $117 \mathrm{~km} / \mathrm{hr}$ ) and Severe Cyclonic Storm (SCS: wind speed $89-117 \mathrm{~km} / \mathrm{hr}$ ) is decreasing, the very intensive tropical cyclones (SCS-H: wind speed $>117 \mathrm{~km} / \mathrm{hr}$ ) are increasing [17].

\subsubsection{Observed changes at local level}

The coastal region is expected to exacerbate many of the current problems and natural hazards due to climate change. The empirical data, during 2007 - 20012, collected from the meteorological station, Khulna gives an overview of the short of changing pattern of the climatic parameters.

\section{Humidity}

In robi season humidity increased in December and decreased in November. In Kharif-I season humidity increased in June and decrease in March. In Kharif-II season humidity increased in 2012 and decrease in 2010 .

\section{Temperature}

The data received indicates that in rabi season the minimum temperature in January was fluctuating with the increasing of year but maximum temperature was decreasing with the increasing of year. Both maximum and minimum temperature in February months was decreasing. The minimum temperature in the months of March was fluctuating with the increasing of year but maximum temperature is almost constant with the increasing of year.

\section{Rainfall}

In Robi season, the rainfall is lowest in 2011, that indicating the draught phenomena. The rainfall was highly increased in October 2010. In Kharip-I season rainfall increased in 2007 and decrease in 2008. In Kharif-II rainfall increased in 2008 and decreased in 2007. 


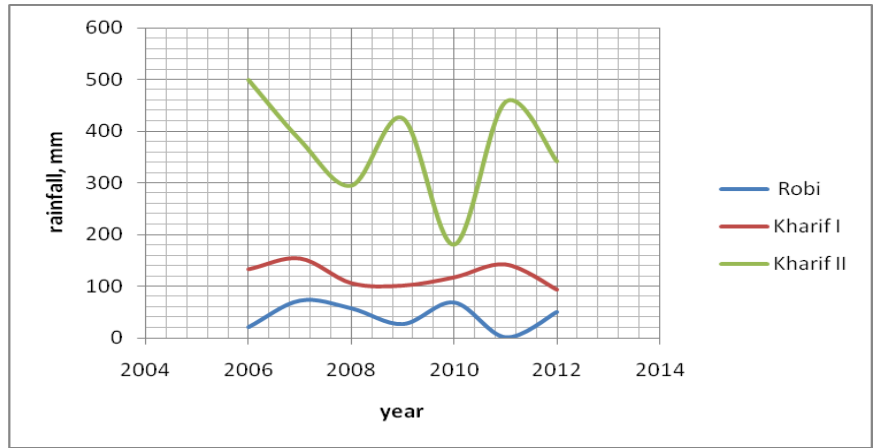

\subsection{Climate change and Crop Production}

Figure III-2: Seasonal Rain fall trends

The changing pattern of climatic conditions affected on the crop in various seasons in the study area. In Rabi season, Boro paddy mainly depends on the rainfall; generally in this season rainfall is low. In 2008 and 2011 rainfall was very low. In this reason Boro paddy, oil yielding crops and Pulses crops production was also very low. Therefore, it indicates that this crop production mainly depend on the rainfall. In these years $(2008$ \& 2010) temperature was also low. But vegetables and Potato crops production was high and species crops was medium

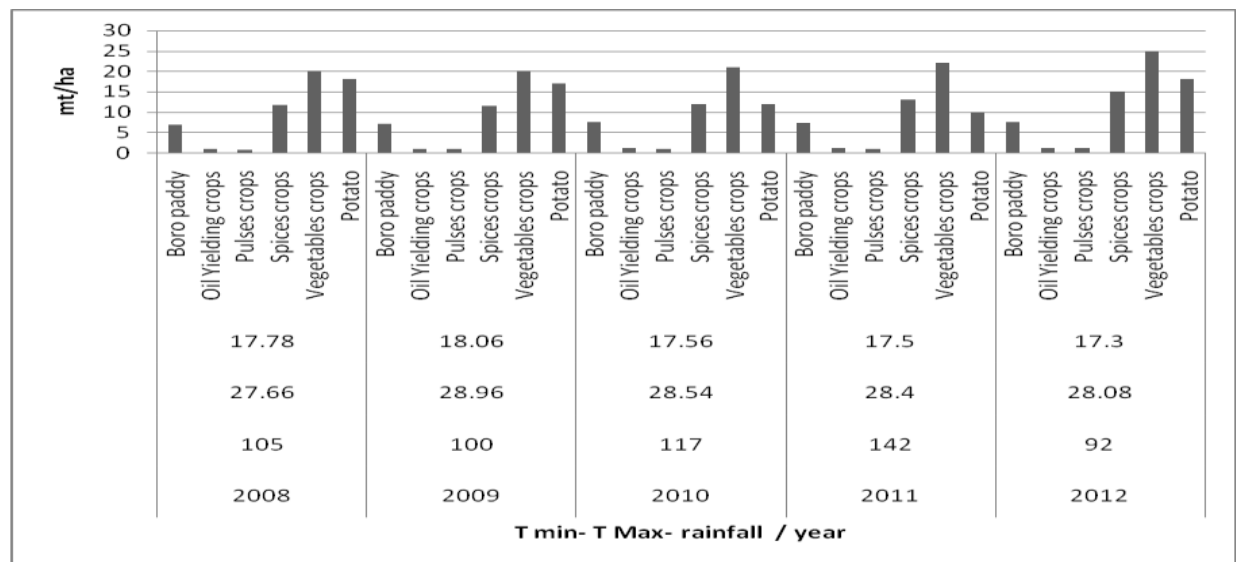

Figure III-3: Crop production in Robi

The Kharif-I season Auas paddy and vegetables production was increased in 2012; Jute and Oil yielding production was medium. In this year temperature and rainfall was normal from the previous years. But in 2011 Auas paddy and Oil Yielding crops production was decreased. In this year rainfall was highly increased but temperature was medium from the previous years. Therefore, it indicates the rainfall was responsible for crop production.

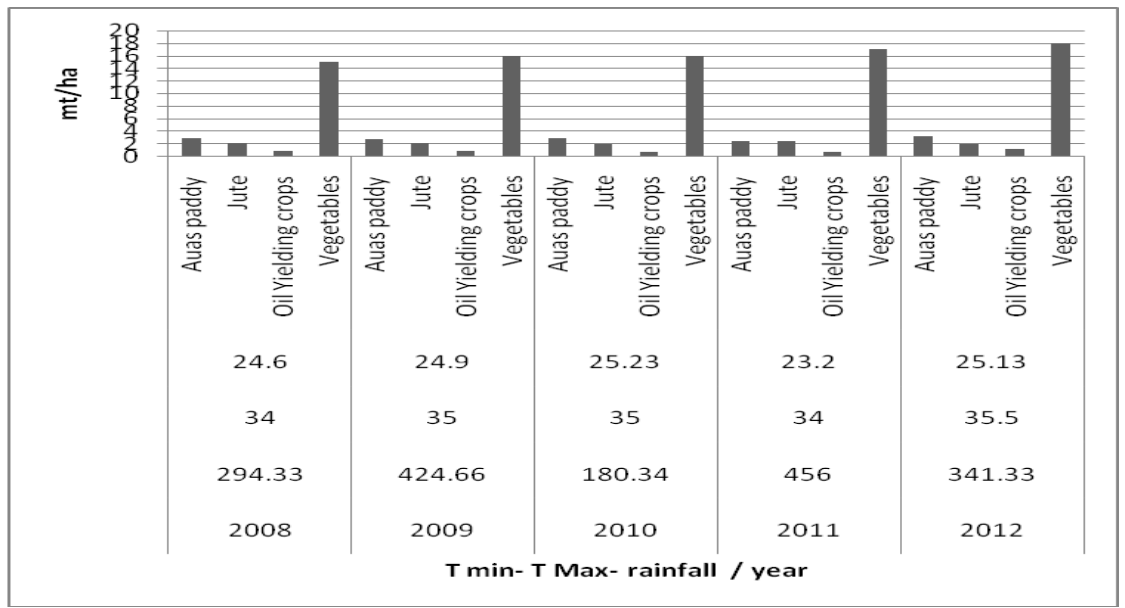

Figure III-4: Crop Production in Kharif I 


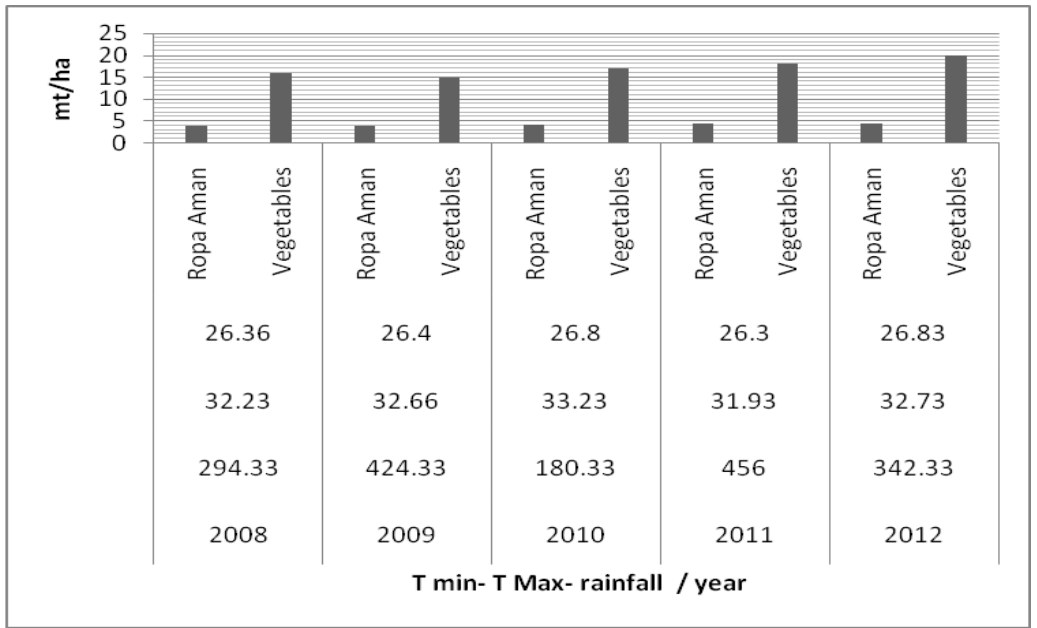

Figure III-5: Crop production in khari II

In Kharif -II crops Ropa Aman production was low in 2009 but it is gradually increased and 2012 its production was high. Vegetables production was also high in 2012 and low in 2009.

\subsection{Climate change and health profile}

\section{Nutritional conditions through FCS}

From survey data, Fig- 3-6 shows that $100 \%$ people main food is rice and the food habit maximum is two times per day. The daily consumption of staple food was $85 \%$ of the respondents and more than $60 \%$ people take other important item e.g. Vegetable five days per week.

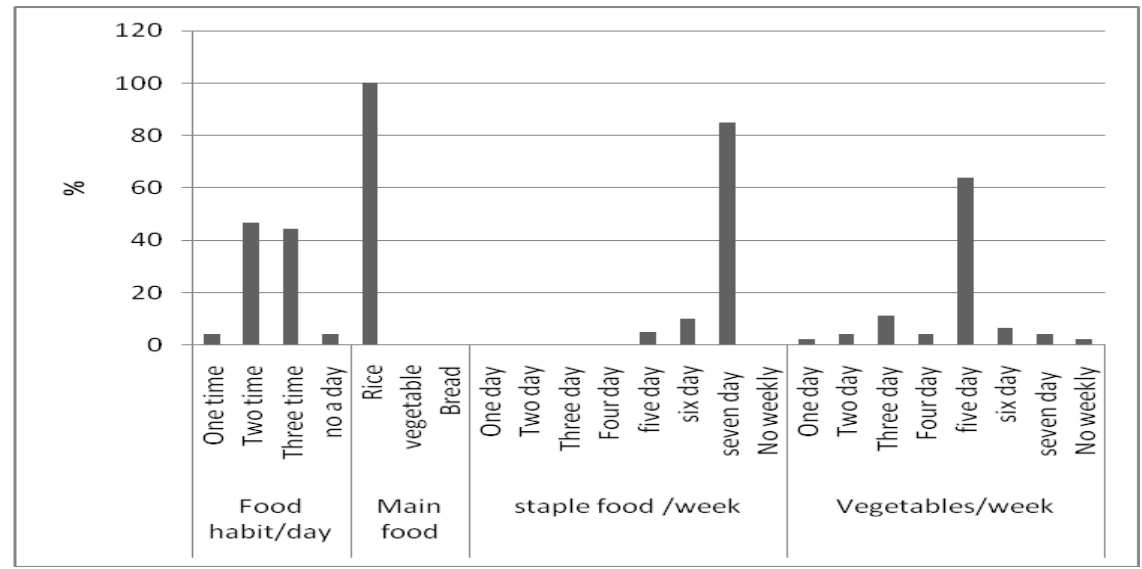

Figure III-6: food habit and food items

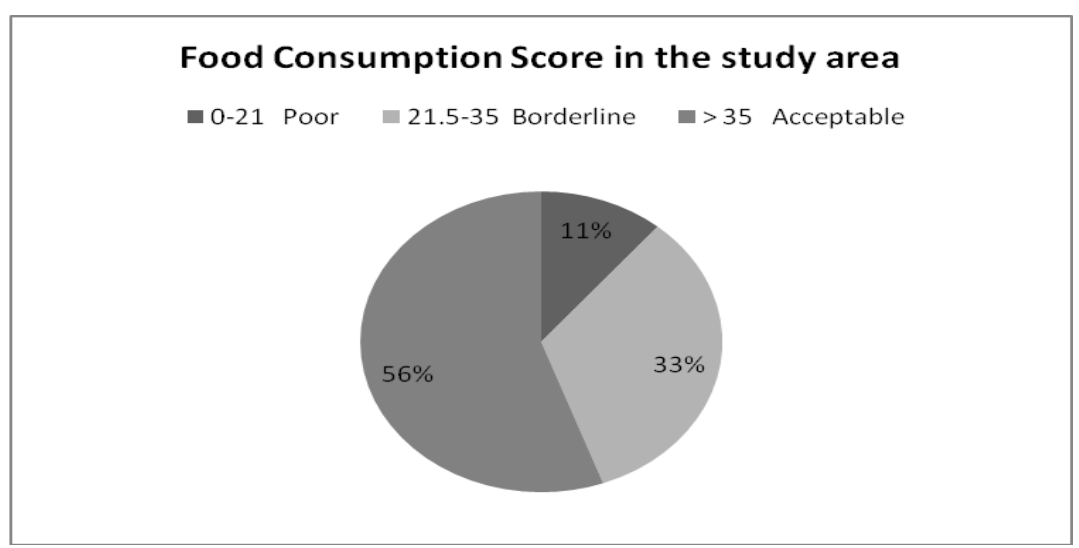

Figure III-7 Food consumption Score at Dumuria, Upazila 
The FCS (Fig 3-7) shows that 56\% people are in acceptable range and about $10 \%$ people are in poor region. Maybe, these are in vulnerable due to poor wealth groups.

\section{Water Supply and Sanitation System}

The water supply and sanitation system of Dumuria Upziala is also remarkable, indicates the survey data, as there is no Arsenic and Iron problem in water. Fig 3-8 shows that people uses $86.67 \%$ public tube well means local tube well, $13.33 \%$ own tube well. The sanitation practice is also well as people of $4.44 \%$ are used unimproved, $66.67 \%$ semi improved, and 28.895 improved toilets. Most of the people are using water after washroom facilities and also use $23.22 \%$ soap, $22.22 \%$ ash and the rest use mud.

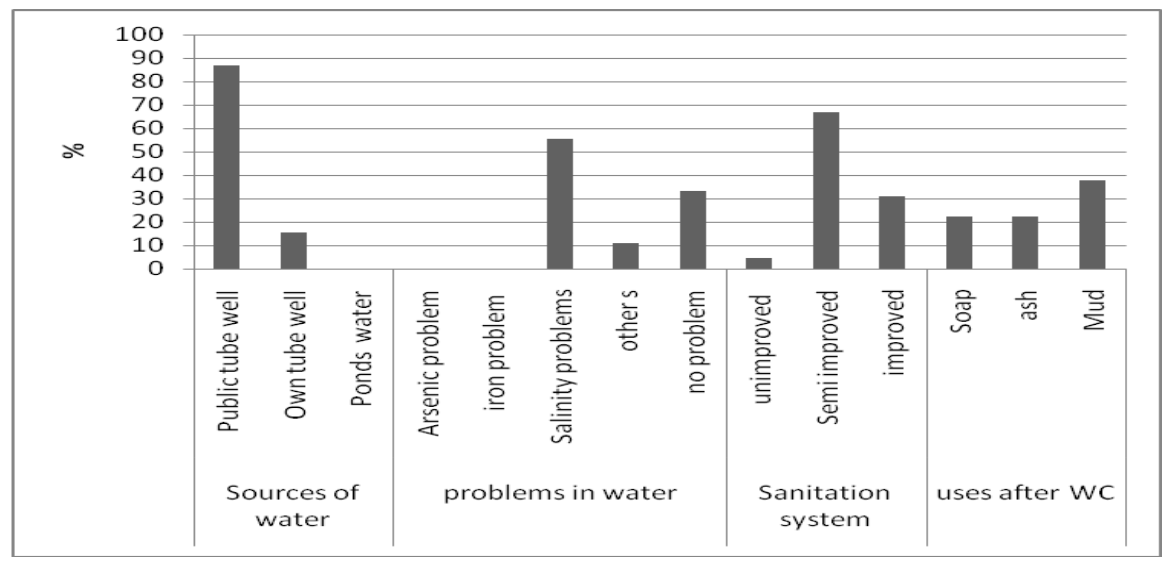

Figure III-8: Water supply and sanitation system

\section{Health and Disease}

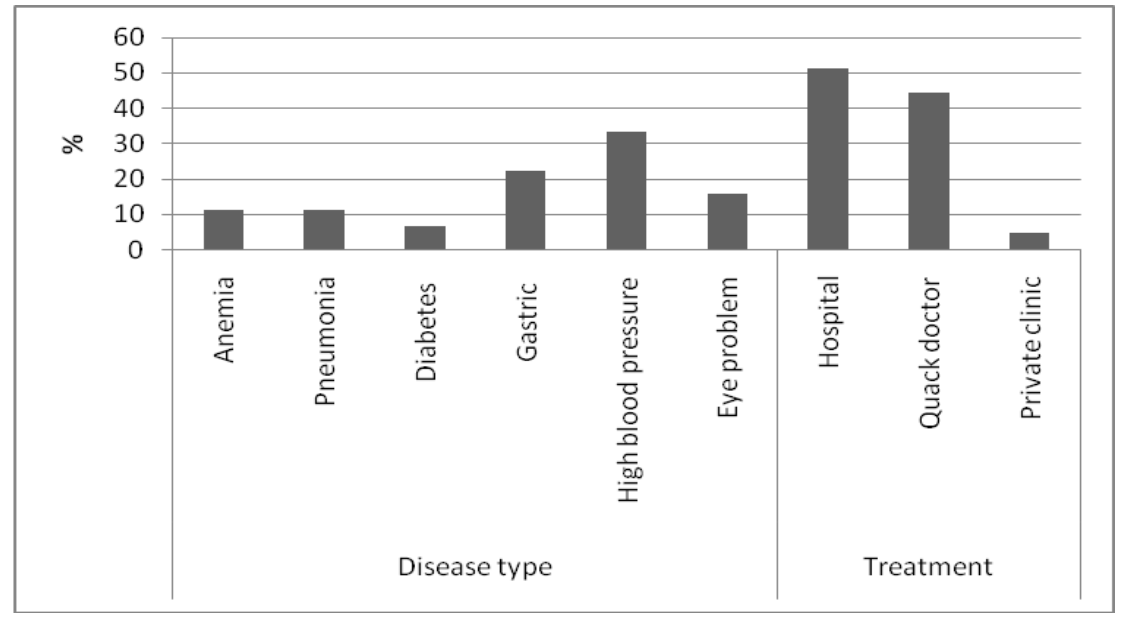

Figure III-9: Health and disease problem

The climate related health problems e.g. anaemia, pneumonia, etc was also evidenced in the study area. $11.11 \%$ patient suffer from Anemia, $11.11 \%$ Pneumonia, $6.67 \%, 22.22 \%$ Gastric, 33.33\% High blood pressure, $15.56 \%$ Eye problem. This people take treatment from $51.11 \%$ hospital, $44.44 \%$ quack doctor, and $4.44 \%$ private clinic (Fig 3-9).

\section{CONCLUSION}

Due to climate change and its consequences i.e. the frequency and magnitude of the natural hazards, it is accepted from the various research and surveys that the exposed coastal region of Bangladesh is the most vulnerable zone. The literature reviews and filed survey also evidences that Dumuria Upazilla, Khulna is also vulnerable as it is situated into the interior coastal region of Bangladesh. From the empirical climatic data, there were observed the fluctuations of humidity, rainfall and temperature. As the data of temperature observed 9 that in rabi season the minimum temperature in and maximum temperature is decreasing, the winter is becoming cooler. But the increasing minimum temperature and constant maximum temperature (higher) indicates the summer is hotter. There were found that the cause of low rain fall, the production of Boro paddy, oil yielding crops and Pulses crops production is very low in Robi. In this reason, temperature is also low. But vegetables 
and Potato crops production is high and species crops is medium. In kharif I, temperature and rainfall is normal, the production is well but with increasing rain fall, the crop production is increased. In kharif II, Ropa amon is gradually increasing, as there are no effect by decreasing rainfall. But vegetables production is high with low rainfall and low with high rainfall. The temperature effect is not significant.

\subsection{Limitations of the study}

There were some limitations of the study. The study conducted was based on the primary and secondary sources of information. There were time limitations to collect primary information. The numbers of sampling are not large; this may cause less acceptable statistical value in the analysis. In some cases, there were unavailability of related experimental in formations; field observations by the author that cause some problem for perfect understanding. The study could not focus the available adaptations and mitigations measures of climate change problems.

\section{REFERENCES}

[1]. Warrick, R.A. and Q.K. Ahmad, The implications of climate and sea-level change for Bangladesh 1996: Kluwer Academic Publishers.

[2]. Warrick, R., E. Barrow, and T.M. Wigley, Climate and sea level change: observations, projections and implications1993: Cambridge University Press.

[3]. IPCC, 4th Assessment Report: The Physical Science Basis-Summary for Policy Makers. Working Group I. 2007.

[4]. Huq, S., H. Reid, and L.A. Murray, Climate change and development links2006: IIED.

[5]. GoB, Bangladesh Climate Change Strategy and Action Plan 2008, 2008

[6]. Rahman, A.a.A., M, Mainstreaming Adaptation to Climate Change in Least Developed Countries, Working Paper 2: Bangladesh Country Case Study, 2003, International Institute for Environment and Development (IIED): London.

[7]. Mahtab, F. and C. Secretariat, Effect of climate change and sea-level rise on Bangladesh 1989.

[8]. Ahmed, A.U., Bangladesh climate change impacts and vulnerability: A synthesis 2006: Climate Change Cell, Department of Environment.

[9]. Pender, J. Community led Adaptation in Bangladesh: Case study. in the 2nd international workshop on community based adaptation to climate change, Dhaka. 2007. Dhaka.

[10]. Banglapedia Climate in Bangladesh. yearly, 2008.

[11]. Brammer, H., Asaduzzaman M. \& Sultana, P, Effects of Climate and Sea-level Changes on the Natural Resources of Bangladesh. Briefing Ducument No. 31993, Dhaka: Bangladesh Unnayan Parishad (BUP).

[12]. BUET, Characterizing Country Settings: Development of a Base Document in the Backdrop of Climate Change Impacts, MoEF, Editor 2008: Dhaka.

[13]. WARPO, Coastal Development Strategy, Water Resources Planning Organization, M.o.W. Resources, Editor 2006: Dhaka Bangladesh.

[14]. Mainuddin, K., et al., Planning and costing agriculture's adaptation to climate change in the salinity-prone cropping system of Bangladesh. 2011.

[15]. GOB, National Adaptation Programme of Action (NAPA), Final report: November 2005, Ministry of Environment and Forest, Editor 2005, Government of the People's Republic of Bangladesh (GOB): Dhaka.

[16]. Ahmed, A.U.a.A., M, Development of Climate Change Scenarios With General Circulation Models, in Vulnerability and Adaptation to Climate Change for Bangladesh, Z.K. S. Huq, M. Asaduzzaman, and F. Mahtab Editor 1998, Kluwer Academic Publishers: Dordrecht.

[17]. Rahman, M.M. Country report: Bangladesh. in Workshop on Climate Change and its Impact on Agriculture 2011. Seoul, Republic of Korea.

[18]. Bank, W., Bangladesh: Climate Change and Sustainable Development. Report No. 21104-BD, 2000, The World Bank (WB): South Asia Region, , Dhaka,

[19]. Centre, S.M.R., The Vulnerability Assessment of the SAARC Coastal Region due to Sea Level Rise: Bangladesh Case.SMRCNo.3, 2003, SMRC Publication: Dhaka, Bangladesh.

[20]. Karim, M.F. and N. Mimura, Impacts of climate change and sea-level rise on cyclonic storm surge floods in Bangladesh. Global environmental change, 2008. 18(3): p. 490-500. 